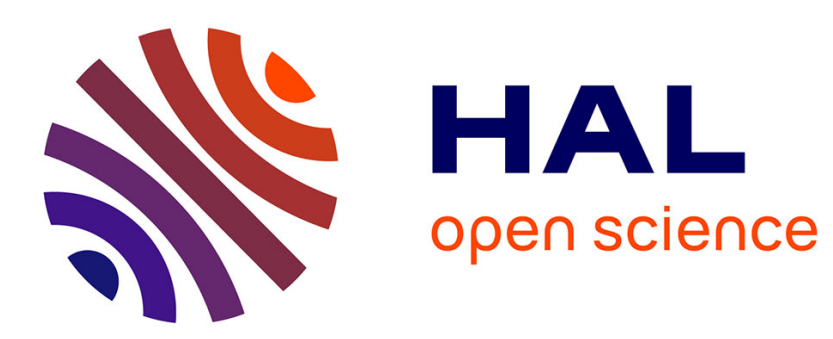

\title{
Genetic variation for seed yield and its components in alfalfa (Medicago sativa L.) populations
}

Eduardo-Daniel Bolaños-Aguilar, Christian Huyghe, Bernadette Julier, Christian Ecalle

\section{- To cite this version:}

Eduardo-Daniel Bolaños-Aguilar, Christian Huyghe, Bernadette Julier, Christian Ecalle. Genetic variation for seed yield and its components in alfalfa (Medicago sativa L.) populations. Agronomie, 2000, 20 (3), pp.333-345. 10.1051/agro:2000131 . hal-00886028

\section{HAL Id: hal-00886028 \\ https://hal.science/hal-00886028}

Submitted on 1 Jan 2000

HAL is a multi-disciplinary open access archive for the deposit and dissemination of scientific research documents, whether they are published or not. The documents may come from teaching and research institutions in France or abroad, or from public or private research centers.
L'archive ouverte pluridisciplinaire $\mathbf{H A L}$, est destinée au dépôt et à la diffusion de documents scientifiques de niveau recherche, publiés ou non, émanant des établissements d'enseignement et de recherche français ou étrangers, des laboratoires publics ou privés. 


\title{
Genetic variation for seed yield and its components in alfalfa (Medicago sativa L.) populations
}

\author{
Eduardo-Daniel Bolaños-Aguilar, Christian HuYGHE*, Bernadette JuliER, \\ Christian ECALLE
}

Unité de Génétique et d'Amélioration de Plantes Fourragères, INRA, Route de Saintes, 86600 Lusignan, France

(Received 4 October 1999; accepted 19 January 2000)

\begin{abstract}
Genetic variation in seed yield and its components was investigated in alfalfa (Medicago sativa L.) in two experiments established in a spaced plant design. The first experiment evaluated the among-population genetic variation in a set of 45 cultivated populations. It showed a significant population effect for all the characters evaluated with a different behavior among the Mediterranean and the Nordic materials while the population $\times$ year interaction was only significant for the seed yield per plant. A second experiment evaluated the genetic variation among and within-populations in a set of 11 populations. The among- and within-population effects were significant for almost all the components. The among-population variance accounted for 5 to $31 \%$ of the total genetic variance for seed yield components, while the within-population variance explained 69 to $95 \%$. In both experiments, the broad-sense heritabilities of characters varied from 0.27 to 0.43 . The number of inflorescences, seed number per plant and seed weight per inflorescence showed high phenotypic and genetic correlations with seed yield per plant. The possibility of using the seed weight per inflorescence as a selection criterion is discussed.
\end{abstract}

alfalfa / seed yield / population / genetic variation / selection criterion

Résumé - Variabilité génétique intra- et inter-population pour le rendement grainier et ses composantes chez la luzerne. Deux essais ont été implantés, en plantes isolées, pour évaluer la variabilité génétique pour le rendement grainier et ses composantes chez la luzerne (Medicago sativa L.). Le premier essai a mis en évidence une variabilité génétique inter-population au sein d'un ensemble de 45 populations cultivées pour toutes les composantes évaluées avec un comportement différent des types nordiques et des types méditerranéens. L’interaction année $\times$ population n'est significative que pour le rendement et le nombre de graines par plante. Le deuxième essai a évalué la variabilité génétique inter- et intra-population dans un ensemble de 11 populations. Les effets inter- et intra-population ont été significatifs pour toutes les composantes. La variance inter-population représente de 5 à $31 \%$ de la variance génétique totale, et la variance intra-population de 69 à $95 \%$ pour les différentes composantes. Les héritabilités au sens large des

Communicated by Mervyn Humphreys (Aberystwyth, UK)

* Correspondence and reprints

huyghe@lusignan.inra.fr 
composantes ont varié de 0,27 à 0,43. Le nombre d'inflorescences et le nombre de graines par plante et le poids de graines par inflorescence sont fortement corrélés phénotypiquement et génétiquement avec le rendement grainier par plante dans un dispositif en plantes isolées. La possibilité d'utiliser certaines composantes relatives à l'inflorescence comme critère de sélection pour le rendement grainier est discutée.

luzerne / rendement grainier / population / variation génétique / critère de sélection

\section{Introduction}

Alfalfa (Medicago sativa L.) is a cross-pollinated autotetraploid forage legume. At present, this species is grown on more than 33000000 ha in the world and the main alfalfa-producing areas are central and eastern Europe, the Mediterranean basin and north America [27]. Variability for agronomic and morphological traits of alfalfa is frequently used in breeding programs for developing cultivars with a high forage production and quality, but seed-yielding ability has rarely been an important criterion in the early stages of selection programs. However, the ability of a cultivar to give a high seed yield determines its effective distribution to farmers at competitive prices. The seed yield of alfalfa is very low $\left(250-400 \mathrm{~kg} \cdot \mathrm{ha}^{-1}\right)$ compared to its high vegetative biomass, up to $8000 \mathrm{~kg} \cdot \mathrm{ha}^{-1}$ [12]. According to Lorenzetti [24], the theoretical seed yield potential in alfalfa calculated from the number of flowers and the number of ovules is $12000 \mathrm{~kg} / \mathrm{ha}$, but the actual seed yield achieved under the most favorable conditions only reaches $4 \%$ of this seed yield potential. Many forage breeders expect a negative correlation between dry matter production and seed yield. However, such a negative correlation between production of dry matter and seed is difficult to demonstrate both in grasses [1] and legumes [23]. In alfalfa, a significant positive phenotypic correlation between seed and forage yield was observed by Boçsa and Buglos [4] and Melton [26], while Heinrichs [15] found no relationship between seed yield and dry matter yield. A positive relationship may be due to architectural attributes such as tall and lodging tolerant stems which would enhance both characters $[13,22]$. The phenotypic correlation between harvest index and seed yield is also highly significant
[33]. Therefore, it should be possible to increase seed yield in alfalfa without a negatively correlated response on forage yield.

Knowledge of the extent of genetic variation for seed yield components remains an important step in alfalfa breeding programs [29]. Hacquet [14] reviewed the relationships between seed yield and its components in alfalfa across varieties and environments. He reported that seed yield was highly correlated with number of seeds per pod, number of inflorescences and number of pods per inflorescence. Seed yield components such as fertility (number of pods per 100 flowers), seed number per pod, mean seed weight, number of inflorescences and number of pods per inflorescence explained differences in seed yield among cultivars. They were used to develop selection criteria for breeding higher yielding cultivars or for selection of germplasm [5]. However, all of these studies evaluated few seed yield components related to the inflorescence itself. Crochemore et al. [8] and Julier et al. [17] have shown a large genetic variability for some morphological and agronomic characters associated with forage and seed yield and quality in alfalfa populations. Because of their genetic structure, the within-population variation was shown to be large for morphological and quality traits [18] as well as for molecular markers [7]. However, nothing is known about the genetic diversity available within the alfalfa populations for the seed yield and seed yield components.

The objectives of the present study were to evaluate genetic variation for seed yield and its components among and within a large range of alfalfa populations grown in a spaced plant design. Major emphasis was given to traits associated with the inflorescence. The possibility of exploiting genetic variation in breeding programs is discussed. 


\section{Materials and methods}

\subsection{Plant material and experimental design}

Two experiments were carried out at the Unité de Génétique et d'Amélioration des Plantes Fourragères, INRA, at Lusignan $\left(46.26^{\circ} \mathrm{N}\right.$; $\left.0.07^{\circ} \mathrm{E}\right)$, France on a loamy-clay soil, $\mathrm{pH} 6.8$. In both experiments, plants were established in a spaced plant design with $70 \mathrm{~cm}$ between plants in both directions. No inoculation was performed prior to transplanting because of the presence of indigenous Rhizobium meliloti populations. Pollination was ensured by native pollinators, and was considered not to be a limiting factor. No irrigation or insecticide were applied during the reproductive development of the plants.

\subsubsection{Among-population variation}

In experiment I, 45 alfalfa populations of different genetic origins (Tab. I) were analyzed to determine the genetic variation for seed yield and its components. The populations were either varieties or local landraces and were chosen to cover a wide range of geographic origin in $M$. sativa ssp. sativa. The populations were classified into two groups of diversity, the cultivated Nordic types including the Flemish material and the cultivated Mediterranean types. The seeds were mechanically scarified to obtain a homogeneous germination. The seeds were germinated in Petri dishes placed for $48 \mathrm{~h}$ in a growth cabinet at $24{ }^{\circ} \mathrm{C}$. The seedlings were then planted in a greenhouse. After 2 months in the greenhouse, the plants were clipped and transplanted into the field on 18 April 1994. The trial was established in a randomized block design with three replications. Each individual plot consisted of 30 random plants. In two consecutive years, 1995 and 1996, seed yield and yield components were analyzed during summer growth. The plots were cut on 14 June and 15 May in 1995 and 1996 respectively.

\subsubsection{Within-population variation}

For experiment II, in February 199711 of the original 45 populations of alfalfa (Tab. I) were selected to evaluate genetic variation among- and
Table I. Origin of the 45 populations of alfalfa studied to assess among-population variation. Populations marked with $(*)$ were used in experiment II.

\begin{tabular}{|c|c|c|}
\hline Population & Origin & Group \\
\hline 3. Dem 3 & Morocco & Mediterranean \\
\hline 4. Pool5 & Morocco & Mediterranean \\
\hline 5. Gabes & Tunisia & Mediterranean \\
\hline * 6. Flamande & France & Nordic \\
\hline 7. Provence & France & Mediterranean \\
\hline 8. Marais de Lucon & France & Nordic \\
\hline 12. Natsuwakaba & Japan & Nordic \\
\hline * 13. Magali & France & Mediterranean \\
\hline * 14. Europe & France & Nordic \\
\hline * 15. Medalfa & France & Mediterranean \\
\hline * 16. Rival & France & Nordic \\
\hline 17. Resis & France & Nordic \\
\hline * 18. Maya & France & Nordic \\
\hline 19. Alègro & France & Nordic \\
\hline * 20. Orca & France & Nordic \\
\hline 21. $63-28 p$ & France & Nordic \\
\hline * 22. Luzelle & France & Nordic \\
\hline 23. Julus & Sweden & Nordic \\
\hline 24. Lodi & Italy & Mediterranean \\
\hline 25. Aragon & Spain & Mediterranean \\
\hline * 26. Ampurdan & Spain & Mediterranean \\
\hline 27. Tierra de Campos & Spain & Mediterranean \\
\hline 28. Mediterraneo & Spain & Mediterranean \\
\hline 29. Totana & Spain & Mediterranean \\
\hline 30. Coussouls & France & Mediterranean \\
\hline 31. Crioula & Brazil & Mediterranean \\
\hline 32. WL514 & USA & Mediterranean \\
\hline 33. Alfagraze & USA & Nordic \\
\hline 34. Altfranken-S-S & Germany & Nordic \\
\hline 35. CUF101 & USA & Mediterranean \\
\hline 36. Radouga & Russia & Nordic \\
\hline 37. $27-48$ & France & Nordic \\
\hline 38. Sewa & Egypt & Mediterranean \\
\hline 39. Chypre & Cyprus & Mediterranean \\
\hline 40. Higazi & Sudan & Mediterranean \\
\hline 42. 2929 & India & Mediterranean \\
\hline * 43. Sabre & Canada & Nordic \\
\hline 44. Victory & Canada & Nordic \\
\hline 45. Rhizoma & Canada & Nordic \\
\hline 46. Lamia & Greece & Mediterranean \\
\hline * 47. Kayserie & Turkey & Mediterranean \\
\hline 48. Lutèce & France & Nordic \\
\hline 49. $63-28 \mathrm{p} \times$ Rival & France & Nordic \\
\hline 50. $63-28 \mathrm{p} \times$ Maya & France & Nordic \\
\hline 51. $68-28 \mathrm{p} \times$ Lutèce & France & Nordic \\
\hline
\end{tabular}


within-populations. Twenty plants per population were randomly picked from the old nursery. Each plant was considered as a different genotype based on the genetic structure of the alfalfa populations. Each genotype was cloned via cuttings to obtain four clones that were rooted in the greenhouse. One month later, these clones were transplanted to the experimental field (15 April 1997). The experimental design consisted of four blocks. A block was formed of 11 populations with 20 genotypes each. The seed yield and its components were analyzed during the first year of growth.

\subsection{Plant characteristics}

In experiment I, seed yield and its components were evaluated in 1995 and 1996 on a plot basis. Prior to harvest, the number of plants per plot was counted. For the measurement of the yield components, the third inflorescence of the longest stem of each plant was sampled. For each plot, the inflorescences were weighed. The two basal pods from each inflorescence were sampled and threshed, and their seeds counted. From these data, the number of seeds per pod, the mean seed weight and the seed weight per pod were calculated. The rest of the inflorescences were threshed and the seed weighed. From these data, the following characters were calculated: seed weight per inflorescence, number of pods per inflorescence, number of seeds per inflorescence. The whole plot was then harvested with a combine and seed weight measured. The seed yield per plant was calculated from the seed yield per plot divided by the plant number per plot.

In experiment II, seed yield and its components were evaluated on an individual plant basis. At maturity, the first four inflorescences of the longest stem were collected and the first five pods of each inflorescence were sampled. These 20 pods were threshed and their seeds weighed and counted to calculate the number of seeds per pod, the seed weight per pod and the mean seed weight. The rest of the four inflorescences was threshed to determine the seed weight per inflorescence. After threshing the rest of the plant, the seed yield per plant was calculated as well as the numbers of seeds and inflorescences per plant.

\subsection{Statistical analysis}

Statistical analyses were carried out using procedures from the SAS program [30].

In experiment I, analysis of variance (ANOVA) was performed with the population effect as random and the block effect as fixed. The model was: $\mathrm{X}_{i j k}=\mu+\mathrm{P}_{i}+\mathrm{Y}_{j}+(\mathrm{PY})_{i j}+\mathrm{b}_{k}+\varepsilon_{i j k}$, where $\mathrm{X}_{i j k}=$ phenotypic value observed of population $i$ in year $j$ for block $k ; \mu=$ grand mean; $\mathrm{P}_{i}=$ effect of population $i$; $\mathrm{Y}_{j}=$ effect of year $j$; $(\mathrm{PY})_{i j}=$ population $i \times$ year $j$ interaction; $\mathrm{b}_{k}=$ effect of block $k ; \varepsilon_{i j k}=$ residual error. Variance components were calculated using the VARCOMP procedure. The standard errors (SE) of variances of the random effects were estimated following Becker [3] as: $\operatorname{SE}\left(\sigma_{g}^{2}\right)=\left(2 / k^{2}\right.$ $\left.\Sigma i\left[\mathrm{MS}_{i}^{2} /\left(\mathrm{f}_{i}+2\right)\right]\right)^{1 / 2}$ where $\mathrm{MS}_{i}=$ mean square of effect $i$ used to estimate the variance component $\mathrm{g}$, $\mathrm{f}_{I}=$ degrees of freedom corresponding to the effect $i, k=$ coefficient of $\sigma^{2}{ }_{\mathrm{g}}$ in $\mathrm{E}\left(\mathrm{MS}_{\mathrm{g}}\right)$. Broad-sense heritabilities were estimated: $h^{2}=\sigma^{2}{ }_{g} /\left(\sigma_{g}^{2}+\sigma^{2}{ }_{\text {gy }}+\right.$ $\sigma_{\mathrm{e}}^{2}$ ) with $\sigma_{\mathrm{g}}^{2}=$ genetic variance, $\sigma_{\mathrm{gy}}^{2}=$ population $\times$ year interaction variance and $\sigma_{e}^{2}=$ error variance. The standard error of these heritabilities $\left[\operatorname{SE}\left(h^{2}\right)\right]$ was calculated using the equation of Becker [3]: $\operatorname{SE}\left(h^{2}\right)=\left\{\operatorname{SE}\left(\sigma_{g}^{2}\right)\right\} / \sigma_{p}^{2}$, where $\sigma_{p}^{2}=$ phenotypic variance and $\sigma_{\mathrm{g}}^{2} \stackrel{\mathrm{g}}{=}$ genotype variance. Phenotypic correlations were calculated using the CORR procedure from the mean data calculated across blocks for each population $\times$ year combination. Genetic correlations were calculated from variance-covariance matrices obtained by the multivariate analysis of variance (MANOVA) procedure for the genotype effects and year $\times$ population interaction.

The structure of genetic variation among the populations based on all the seed yield characteristics was analyzed using a principal component analysis (PCA) on the centred and standardized variates using the mean population value across the three replications and the two years.

In experiment II, populations and genotypes within populations were considered as random effects and the block effect as fixed in the ANOVA, performed with the GLM procedure. The model was: $\mathrm{Y}_{i j k}=\mu+\mathrm{P}_{i}+\mathrm{g}(\mathrm{P})_{i j}+\mathrm{b}_{k}+\varepsilon_{i j k}$, where $\mathrm{Y}_{i j k}=$ 
phenotypic value observed of genotype $j$ of population $i$ for block $k ; \mu=$ grand mean; $\mathrm{P}_{i}=$ effect of population $i ; \mathrm{g}(\mathrm{P})_{i j}=$ genotype $j$ within population $i$; $\mathrm{b}_{k}=$ effect of block $k ; \varepsilon_{i j k}=$ residual error. The variance components were calculated as in experiment I. Broad-sense heritabilities were estimated according to Gallais [10] as: $\mathrm{h}^{2}=\left(\sigma_{\mathrm{p}}^{2}+\sigma_{\mathrm{g}(\mathrm{p})}^{2}\right) /\left(\sigma_{\mathrm{p}}^{2}+\right.$ $\sigma_{\mathrm{g}(\mathrm{p})}^{2}+\sigma_{\mathrm{e}}^{2}$ ) with $\sigma_{\mathrm{p}}^{2}=$ for among-population variance, $\sigma_{g(p)}^{2}=$ for within-population variance and $\sigma^{2}{ }_{\mathrm{e}}$ $=$ error variance. Standard errors of the variance components and of the heritabilities were calculated as in experiment I. The phenotypic correlations were calculated on the mean of the genotypes across blocks. The genotype correlations were calculated from variance-covariance matrices obtained by the MANOVA procedure for the genotype effect and error term from an analysis of variance where no population effect was declared. This allowed all the genetic variation to be taken into account.

\section{Results}

\subsection{Among-population variation}

The ANOVA for the 45 cultivated populations is shown in Table II. It showed a highly significant population effect $(\mathrm{P}<0.001)$ for all of the characters evaluated. The year effect was also highly significant for all the components, except for seed weight per pod and number of seeds per pod.
The year $\times$ population interaction effect was only found to be highly significant $(P<0.001)$ for seed yield per plant and number of seeds per plant. However, the population effect for these components remained significant when tested against the interaction. The populations which contributed the most to the year $\times$ population interaction were some of the Mediterranean populations which yielded poorly in the second year of seed harvest. Indeed, some of these populations with low autumn dormancy tended to produce weak plants with few fertile stems per plant.

The estimates of variance components and broad-sense heritabilities are shown in Table III. The population variance was larger than the year $\times$ population interaction variance for all the components evaluated. It contributed up to 14.4 and $15.2 \%$ of the total phenotypic variance, for seed yield and the number of seeds per plant respectively. A large error variance was observed for all the components, especially for the number of inflorescences per plant. This led to low broad-sense heritability values, which varied from 0.28 to 0.42 . The highest heritabilities were observed for the seed yield per plant, the seed weight per inflorescence and the number of seeds per inflorescence. The lowest heritability was for the number of inflorescences per plant.

Phenotypic and genetic correlations for all the components evaluated are presented in Table IV. Seed yield per plant showed strong and positive

Table II. ANOVA of the different sources of variation for the two experiments.

\begin{tabular}{|c|c|c|c|c|c|}
\hline \multirow[t]{2}{*}{ Character } & \multicolumn{3}{|c|}{ Experiment I (45 populations) } & \multicolumn{2}{|c|}{ Experiment II (11 populations) } \\
\hline & Population & Year & Year $\times$ population & Among-population & Within-population \\
\hline 1. Seed yield / plant & $* * *$ & $* * *$ & $* * *$ & $* *$ & $* * *$ \\
\hline 2. No. of seeds / plant & $* * *$ & $* *$ & $* * *$ & ns & $* * *$ \\
\hline 3. No. of inflorescences/ plant & $* * *$ & $* * * *$ & ns & $* * *$ & $* * *$ \\
\hline 4. Seed weight / inflorescence & $* * *$ & $* *$ & ns & $* * *$ & $* * *$ \\
\hline 5. No. of pods/inflorescence & $* * *$ & $* * *$ & ns & $* * *$ & $* * *$ \\
\hline 6. No. of seeds/inflorescence & $* * *$ & $* * *$ & ns & $* * *$ & $* * *$ \\
\hline 7. Seed weight/pod & $* * *$ & ns & ns & $* *$ & $* * *$ \\
\hline 8. No. of seeds/pod & $* * *$ & ns & ns & $* * *$ & $* * *$ \\
\hline 9. Mean seed weight & $* * *$ & $* * *$ & ns & $* * *$ & $* * *$ \\
\hline d.f. & 44 & 1 & 44 & 10 & 203 \\
\hline
\end{tabular}

ns: not significant; $* * *, * * *$ significant at the $0.05,0.01$ and 0.001 levels, respectively; d.f.: degrees of freedom. 
Table III. Mean, estimates of variance components and heritability among 45 populations of experiment I for seed yield and its components. Standard errors (SE) are given in brackets.

\begin{tabular}{|c|c|c|c|c|c|}
\hline Character & Mean & $\begin{array}{l}\text { Population } \\
\text { variance } \\
\left(\sigma_{\mathrm{p}}^{2}\right)\end{array}$ & $\begin{array}{c}\text { Population } \times \text { year } \\
\text { interaction } \\
\text { variance } \\
\left(\sigma_{\mathrm{p} \times \mathrm{y}}^{2}\right)\end{array}$ & $\begin{array}{c}\text { Error } \\
\text { variance } \\
\left(\sigma_{\mathrm{e}}^{2}\right)\end{array}$ & $\begin{array}{c}\text { Broad-sense } \\
\text { heritability } \\
\qquad\left(\mathrm{h}^{2}\right)\end{array}$ \\
\hline Seed yield / plant (g) & 37.32 & $\begin{array}{l}67.204 \\
(19.40)\end{array}$ & $\begin{array}{c}22.821 \\
(9.82)\end{array}$ & $\begin{array}{c}68.531 \\
(7.22)\end{array}$ & $\begin{array}{c}0.42 \\
(0.12)\end{array}$ \\
\hline No. of seeds / plant $\left(10^{3}\right)$ & 17.52 & $\begin{array}{c}14.493 \\
(4.40)\end{array}$ & $\begin{array}{l}5.720 \\
(2.48)\end{array}$ & $\begin{array}{c}17.438 \\
(1.83)\end{array}$ & $\begin{array}{c}0.38 \\
(0.11)\end{array}$ \\
\hline No. of inflorescences / plant & 336.7 & $\begin{array}{l}5155.38 \\
(1603.4)\end{array}$ & $\begin{array}{c}108.88 \\
(1000.0)\end{array}$ & $\begin{array}{c}12579.88 \\
(1326.0)\end{array}$ & $\begin{array}{c}0.28 \\
(0.08)\end{array}$ \\
\hline Seed weight / inflorescence (mg) & 117.3 & $\begin{array}{c}401.256 \\
(103.7)\end{array}$ & $\begin{array}{c}20.888 \\
(45.3)\end{array}$ & $\begin{array}{c}531.403 \\
(56.01)\end{array}$ & $\begin{array}{c}0.42 \\
(0.10)\end{array}$ \\
\hline No. of pods / inflorescences & 14.63 & $\begin{array}{l}2.022 \\
(0.63)\end{array}$ & $\begin{array}{c}0.518 \\
(0.38)\end{array}$ & $\begin{array}{l}3.689 \\
(0.38)\end{array}$ & $\begin{array}{c}0.32 \\
(0.10)\end{array}$ \\
\hline No. of seeds / inflorescences & 54.74 & $\begin{array}{l}77.420 \\
(20.75)\end{array}$ & $\begin{array}{l}7.165 \\
(8.93)\end{array}$ & $\begin{array}{l}97.233 \\
(10.24)\end{array}$ & $\begin{array}{c}0.42 \\
(0.11)\end{array}$ \\
\hline Seed weight / pod (mg) & 7.98 & $\begin{array}{l}0.809 \\
(0.20)\end{array}$ & $\begin{array}{c}0.0 \\
(0.07)\end{array}$ & $\begin{array}{c}1.259 \\
(0.002)\end{array}$ & $\begin{array}{c}0.39 \\
(0.09)\end{array}$ \\
\hline No. of seeds / pod & 3.72 & $\begin{array}{l}0.130 \\
(0.03)\end{array}$ & $\begin{array}{c}0.0 \\
(0.01)\end{array}$ & $\begin{array}{l}0.211 \\
(0.02)\end{array}$ & $\begin{array}{c}0.38 \\
(0.08)\end{array}$ \\
\hline Mean seed weight (mg) & 2.14 & $\begin{array}{c}0.014 \\
(0.003)\end{array}$ & $\begin{array}{c}0.0 \\
(0.001)\end{array}$ & $\begin{array}{c}0.021 \\
(0.002)\end{array}$ & $\begin{array}{c}0.40 \\
(0.08)\end{array}$ \\
\hline
\end{tabular}

Table IV. Phenotypic and genetic correlation coefficients from experiments I and II (in bold). Phenotypic and genetic correlations are on the right and left sides of the diagonal, respectively.

\begin{tabular}{|c|c|c|c|c|c|c|c|c|c|}
\hline Character & 1 & 2 & 3 & 4 & 5 & 6 & 7 & 8 & 9 \\
\hline Seed yield/plant & & $\begin{array}{l}0.97 * * * \\
\mathbf{0 . 9 5} * * *\end{array}$ & $\begin{array}{l}0.70 * * * \\
\mathbf{0 . 8 2} * * *\end{array}$ & $\begin{array}{c}0.30 * * \\
\mathbf{0 . 3 8} * * *\end{array}$ & $\begin{array}{l}0.39 * * * \\
\mathbf{0 . 2 6}^{* * * *}\end{array}$ & $\begin{array}{c}0.32 * * \\
\mathbf{0 . 2 9} * * *\end{array}$ & $\begin{array}{c}0.05 \mathrm{~ns} \\
\mathbf{0 . 2 6} * * *\end{array}$ & $\begin{array}{c}0.07 \mathrm{~ns} \\
\mathbf{0 . 1 7} *\end{array}$ & $\begin{array}{c}-0.01 \mathrm{~ns} \\
\mathbf{0 . 1 8}^{* *}\end{array}$ \\
\hline No. of seeds/plant & $\begin{array}{l}0.98 \\
0.96\end{array}$ & & $\begin{array}{l}0.69 * * * \\
\mathbf{0 . 7 9} * * *\end{array}$ & $\begin{array}{c}0.25^{*} \\
\mathbf{0 . 3 4} * * *\end{array}$ & $\begin{array}{l}0.41 * * * \\
\mathbf{0 . 3 2} * * *\end{array}$ & $\begin{array}{c}0.34 * * \\
\mathbf{0 . 3 9} * * *\end{array}$ & $\begin{array}{c}-0.03 \mathrm{~ns} \\
\mathbf{0 . 1 6}^{*}\end{array}$ & $\begin{array}{c}0.08 \mathrm{~ns} \\
\mathbf{0 . 2 3}^{* * *}\end{array}$ & $\begin{array}{l}-0.20 \mathrm{~ns} \\
\mathbf{- 0 . 0 5} \mathbf{~ n s}\end{array}$ \\
\hline No. of inflorescences/plant & $\begin{array}{l}0.75 \\
\mathbf{0 . 8 1}\end{array}$ & $\begin{array}{l}0.74 \\
\mathbf{0 . 7 8}\end{array}$ & & $\begin{array}{l}-0.40 * * * \\
-\mathbf{0 . 0 8} \text { ns }\end{array}$ & $\begin{array}{c}-0.22^{*} \\
-\mathbf{0 . 0 1} \text { ns }\end{array}$ & $\begin{array}{l}-0.39 * * * \\
-\mathbf{0 . 1 2} \text { ns }\end{array}$ & $\begin{array}{c}-0.45^{* * *} \\
-\mathbf{0 . 0 8} \mathbf{~ n s}\end{array}$ & $\begin{array}{c}-0.47 * * * \\
-\mathbf{0 . 1 6}\end{array}$ & $\begin{array}{c}-0.05 \mathrm{~ns} \\
\mathbf{0 . 1 1} \mathbf{n s}\end{array}$ \\
\hline Seed weight/inflorescence & $\begin{array}{l}0.43 \\
\mathbf{0 . 4 6}\end{array}$ & $\begin{array}{l}0.37 \\
\mathbf{0 . 4 3}\end{array}$ & $\begin{array}{l}-0.30 \\
-\mathbf{0 . 0 6}\end{array}$ & & $\begin{array}{l}0.80 * * * \\
\mathbf{0 . 5 6} * * * *\end{array}$ & $\begin{array}{l}0.94 * * * \\
0.85 * * *\end{array}$ & $\begin{array}{l}0.75 * * * \\
0.73 * * *\end{array}$ & $\begin{array}{l}0.72 * * * \\
\mathbf{0 . 6 4} * * *\end{array}$ & $\begin{array}{c}0.22 \mathrm{~ns} \\
\mathbf{0 . 2 4} * * *\end{array}$ \\
\hline No. of pods/inflorescence & $\begin{array}{l}0.48 \\
\mathbf{0 . 3 3}\end{array}$ & $\begin{array}{l}0.49 \\
\mathbf{0 . 4 1}\end{array}$ & $\begin{array}{c}-0.11 \\
\mathbf{0 . 0 3}\end{array}$ & $\begin{array}{l}0.81 \\
\mathbf{0 . 5 5}\end{array}$ & & $\begin{array}{l}0.85 * * * \\
\mathbf{0 . 6 3} * * *\end{array}$ & $\begin{array}{c}0.22^{*} \\
-\mathbf{0 . 1 2} \text { ns }\end{array}$ & $\begin{array}{c}0.32 * * \\
-\mathbf{0 . 0 0 1} \mathbf{~ n s}\end{array}$ & $\begin{array}{c}-0.14 \mathrm{~ns} \\
\mathbf{- 0 . 1 7}\end{array}$ \\
\hline No. of seeds/inflorescence & $\begin{array}{l}0.40 \\
\mathbf{0 . 3 6}\end{array}$ & $\begin{array}{l}0.41 \\
\mathbf{0 . 4 7}\end{array}$ & $\begin{array}{l}-0.32 \\
\mathbf{- 0 . 1 1}\end{array}$ & $\begin{array}{l}0.95 \\
\mathbf{0 . 8 7}\end{array}$ & $\begin{array}{l}0.86 \\
\mathbf{0 . 6 2}\end{array}$ & & $\begin{array}{l}0.61 * * * \\
\mathbf{0 . 4 8} * * *\end{array}$ & $\begin{array}{l}0.75 * * * \\
0.74 * * *\end{array}$ & $\begin{array}{l}-0.10 \mathrm{~ns} \\
\mathbf{0 . 2 6} \text { **** }\end{array}$ \\
\hline Seed weight/pod & $\begin{array}{l}0.19 \\
\mathbf{0 . 3 1}\end{array}$ & $\begin{array}{l}0.10 \\
\mathbf{0 . 2 1}\end{array}$ & $\begin{array}{l}-0.42 \\
-\mathbf{0 . 0 8}\end{array}$ & $\begin{array}{l}0.84 \\
\mathbf{0 . 7 8}\end{array}$ & $\begin{array}{c}0.36 \\
-\mathbf{0 . 1 0}\end{array}$ & $\begin{array}{l}0.72 \\
\mathbf{0 . 5 4}\end{array}$ & & $\begin{array}{l}0.85 * * * \\
\mathbf{0 . 7 8} * * *\end{array}$ & $\begin{array}{l}0.48 * * * \\
\mathbf{0 . 4 5} * * *\end{array}$ \\
\hline No. of seeds/pod & $\begin{array}{l}0.16 \\
0.22\end{array}$ & $\begin{array}{l}0.17 \\
\mathbf{0 . 2 8}\end{array}$ & $\begin{array}{l}-0.48 \\
\mathbf{- 0 . 1 7}\end{array}$ & $\begin{array}{l}0.80 \\
\mathbf{0 . 7 5}\end{array}$ & $\begin{array}{l}0.45 \\
\mathbf{0 . 0 7}\end{array}$ & $\begin{array}{l}0.84 \\
\mathbf{0 . 8 2}\end{array}$ & $\begin{array}{l}0.88 \\
\mathbf{0 . 8 2}\end{array}$ & & $\begin{array}{c}-0.02 \mathrm{~ns} \\
\mathbf{- 0 . 1 7}\end{array}$ \\
\hline Mean seed weight & $\begin{array}{l}0.10 \\
\mathbf{0 . 1 8}\end{array}$ & $\begin{array}{l}-0.10 \\
-\mathbf{0 . 0 7}\end{array}$ & $\begin{array}{l}0.02 \\
\mathbf{0 . 1 3}\end{array}$ & $\begin{array}{l}0.26 \\
\mathbf{0 . 1 5}\end{array}$ & $\begin{array}{l}-0.11 \\
-\mathbf{0 . 2 9}\end{array}$ & $\begin{array}{l}-0.05 \\
-\mathbf{0 . 3 3}\end{array}$ & $\begin{array}{l}0.47 \\
\mathbf{0 . 4 0}\end{array}$ & $\begin{array}{l}-0.01 \\
-\mathbf{0 . 1 7}\end{array}$ & \\
\hline
\end{tabular}

ns: non significant; $*, * * * * *$ significant at the $0.05,0.01$ and 0.001 level, respectively. 
phenotypic and genetic correlations with number of seeds per plant, number of inflorescences per plant, and to a lesser extent with seed weight per inflorescence, and number of pods and seeds per inflorescence. The first two characters are very variable in a spaced plant design as the plants may reach contrasting stages of development and produce a contrasting number of fertile stems. The relationship between the number of inflorescences per plant and the seed yield is shown for both years in Figure 1. The correlations were significant except for the Nordic group in the first year of study. The phenotypic correlation between the seed weight per inflorescence and the seed yield was 0.30 . The relationship between these traits displays a complex pattern, as shown over both years for the Nordic and Mediterranean groups in Figure 2. The relationship was positive both for the Nordic and the Mediterranean groups in the first year of seed harvest, and remained significant for the Nordic group in the second year. The lack of relationship for the Mediterranean group in the second year was due to the poor growth of some populations, as stated above with regard to the year $x$ population interactions. The number of inflorescences per plant had significantly negative phenotypic and genetic correlations with almost all the components except for seed yield per plant and seed number per plant. The seed weight per inflorescence was positively related at the phenotypic and genetic level with the number of seeds and pods per inflorescence. Traits concerning the pod were not correlated with seed yield. The number of seeds and seed weight per pod were positively related to seed weight per inflorescence or per pod. Mean seed weight was only related to seed weight per pod which reflects the narrow range of variation available for this trait.
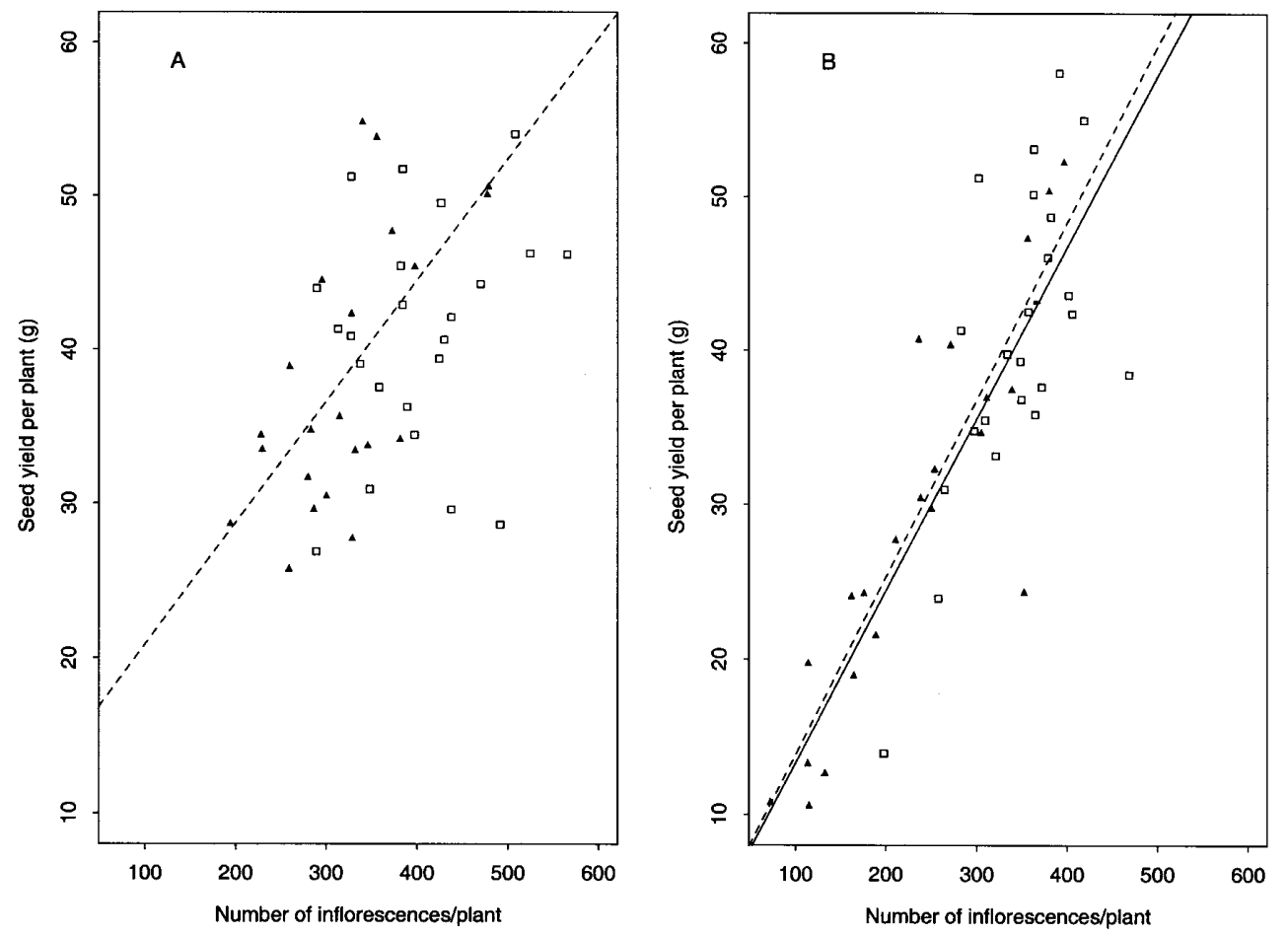

Figure 1. The relationship between number of inflorescence per plant and seed yield per plant in 1995 (A) and 1996 (B). A regression line is given when the correlations are significant. A solid line refers to the Nordic group and a dashed line to the Mediterranean group. Symbols: $\boldsymbol{\Delta}$ : Mediterranean populations; $\square$ : Nordic populations. 

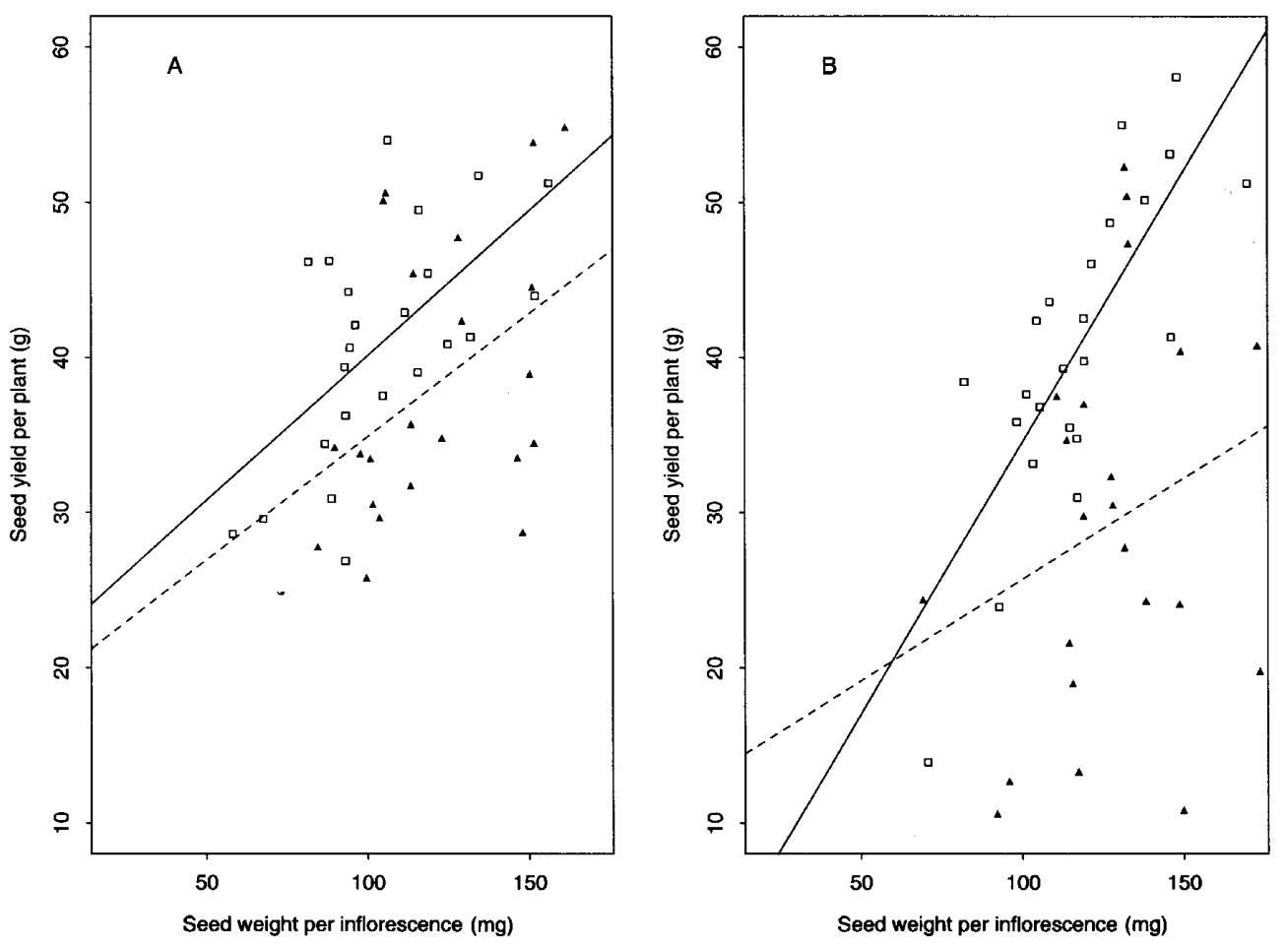

Figure 2. The relationship between seed weight per inflorescence and seed yield per plant in 1995 (A) and 1996 (B). A regression line is given when the correlations are significant. A solid line refers to the Nordic group and a dashed line to the Mediterranean group. Symbols: $\boldsymbol{\Delta}$ : Mediterranean populations; $\square$ : Nordic populations.

The PCA based on the nine seed yield traits tended to separate the Mediterranean populations from the Nordic group (Fig. 3). Both groups were similarly distributed along the first axis which accounted for $48 \%$ of the total variation, but they were separated by the second axis which accounted for $31 \%$ of the total variation. More seeds per pod (3.85 versus 3.59$)$ and a higher seed weight per pod (8.41 versus $7.56 \mathrm{mg}$ ) characterized the Mediterranean group, while the Nordic group had more inflorescences per plant (384 versus 286 ) and produced a higher seed yield per plant (40.75 versus $33.72 \mathrm{~g}$ ).

\subsection{Within-population variation}

The mean values for seed yield and seed yield components were lower in experiment II, where both the among-population and the within- population variances were evaluated, compared to experiment I (Tab. V). This is likely due to the fact that the data for experiment II was collected in the first year after field transplantation and that the plants originated from rooted cuttings.

The results of the ANOVA are presented in Table II. The among- and within-population effects were significant $(\mathrm{P}<0.001)$ for all the characters evaluated, except for the number of seeds per plant among-populations. The estimates of among- and within-population variance components and broadsense heritabilities are presented in the Table V. As in experiment $\mathrm{I}$, the error variance was large for all the components evaluated. It accounted for 57 to $81 \%$ of the total phenotypic variance, depending on the character. The within-population variance was larger than the among-population variance for all the seed yield components. The within-population variance contributed from 69 to $95 \%$ of the 
Table V. Mean, estimates of variance components among and within 11 alfalfa populations of experiment II and heritability of seed yield and seed yield components. Standard errors (SE) are given in brackets.

\begin{tabular}{|c|c|c|c|c|c|}
\hline Character & Mean & $\begin{array}{l}\text { Among population } \\
\text { variance } \\
\left(\sigma_{\mathrm{p}}^{2}\right)\end{array}$ & $\begin{array}{c}\text { Within } \\
\text { population } \\
\text { variance } \\
\left(\sigma_{\mathrm{g}(\mathrm{p})}^{2}\right)\end{array}$ & $\begin{array}{c}\text { Error } \\
\text { variance } \\
\left(\sigma_{\mathrm{e}}^{2}\right)\end{array}$ & $\begin{array}{c}\text { Broad-sense } \\
\text { heritability } \\
\qquad\left(\mathrm{h}^{2}\right)\end{array}$ \\
\hline Seed yield/plant (g) & 15.31 & $\begin{array}{l}3.868 \\
(2.64)\end{array}$ & $\begin{array}{c}32.116 \\
(4.87)\end{array}$ & $\begin{array}{c}50.776 \\
(3.29)\end{array}$ & $\begin{array}{c}0.41 \\
(0.08)\end{array}$ \\
\hline No. of seeds/plant $\left(10^{3}\right)$ & 8.25 & $\begin{array}{l}0.502 \\
(0.56)\end{array}$ & $\begin{array}{l}10.031 \\
(1.54)\end{array}$ & $\begin{array}{l}16.227 \\
(1.05)\end{array}$ & $\begin{array}{c}0.39 \\
(0.07)\end{array}$ \\
\hline No. of inflorescences/plant & 191.60 & $\begin{array}{l}1796.66 \\
(945.78)\end{array}$ & $\begin{array}{l}5055.74 \\
(802.30)\end{array}$ & $\begin{array}{l}9075.49 \\
(590.15)\end{array}$ & $\begin{array}{c}0.43 \\
(0.10)\end{array}$ \\
\hline Seed weight/inflorescence (mg) & 82.76 & $\begin{array}{l}68.613 \\
(39.63)\end{array}$ & $\begin{array}{l}193.99 \\
(38.96)\end{array}$ & $\begin{array}{l}592.75 \\
(38.42)\end{array}$ & $\begin{array}{c}0.31 \\
(0.09)\end{array}$ \\
\hline No. of pods/inflorescences & 10.96 & $\begin{array}{l}0.606 \\
(0.34)\end{array}$ & $\begin{array}{l}1.656 \\
(0.36)\end{array}$ & $\begin{array}{l}6.066 \\
(0.39)\end{array}$ & $\begin{array}{c}0.27 \\
(0.08)\end{array}$ \\
\hline No. of seeds/inflorescences & 44.87 & $\begin{array}{l}27.573 \\
(14.50)\end{array}$ & $\begin{array}{l}62.586 \\
(11.84)\end{array}$ & $\begin{array}{l}170.90 \\
(11.04)\end{array}$ & $\begin{array}{c}0.34 \\
(0.10)\end{array}$ \\
\hline Seed weight/pod (mg) & 7.62 & $\begin{array}{l}0.243 \\
(0.16)\end{array}$ & $\begin{array}{l}1.479 \\
(0.25)\end{array}$ & $\begin{array}{l}3.202 \\
(0.20)\end{array}$ & $\begin{array}{c}0.34 \\
(0.08)\end{array}$ \\
\hline No. of seeds/pod & 4.10 & $\begin{array}{l}0.096 \\
(0.05)\end{array}$ & $\begin{array}{c}0.361 \\
(0.057)\end{array}$ & $\begin{array}{l}0.660 \\
(0.04)\end{array}$ & $\begin{array}{c}0.40 \\
(0.09)\end{array}$ \\
\hline Mean seed weight (mg) & 1.87 & $\begin{array}{c}0.007 \\
(0.004)\end{array}$ & $\begin{array}{c}0.027 \\
(0.005)\end{array}$ & $\begin{array}{c}0.081 \\
(0.005)\end{array}$ & $\begin{array}{c}0.30 \\
(0.09)\end{array}$ \\
\hline
\end{tabular}
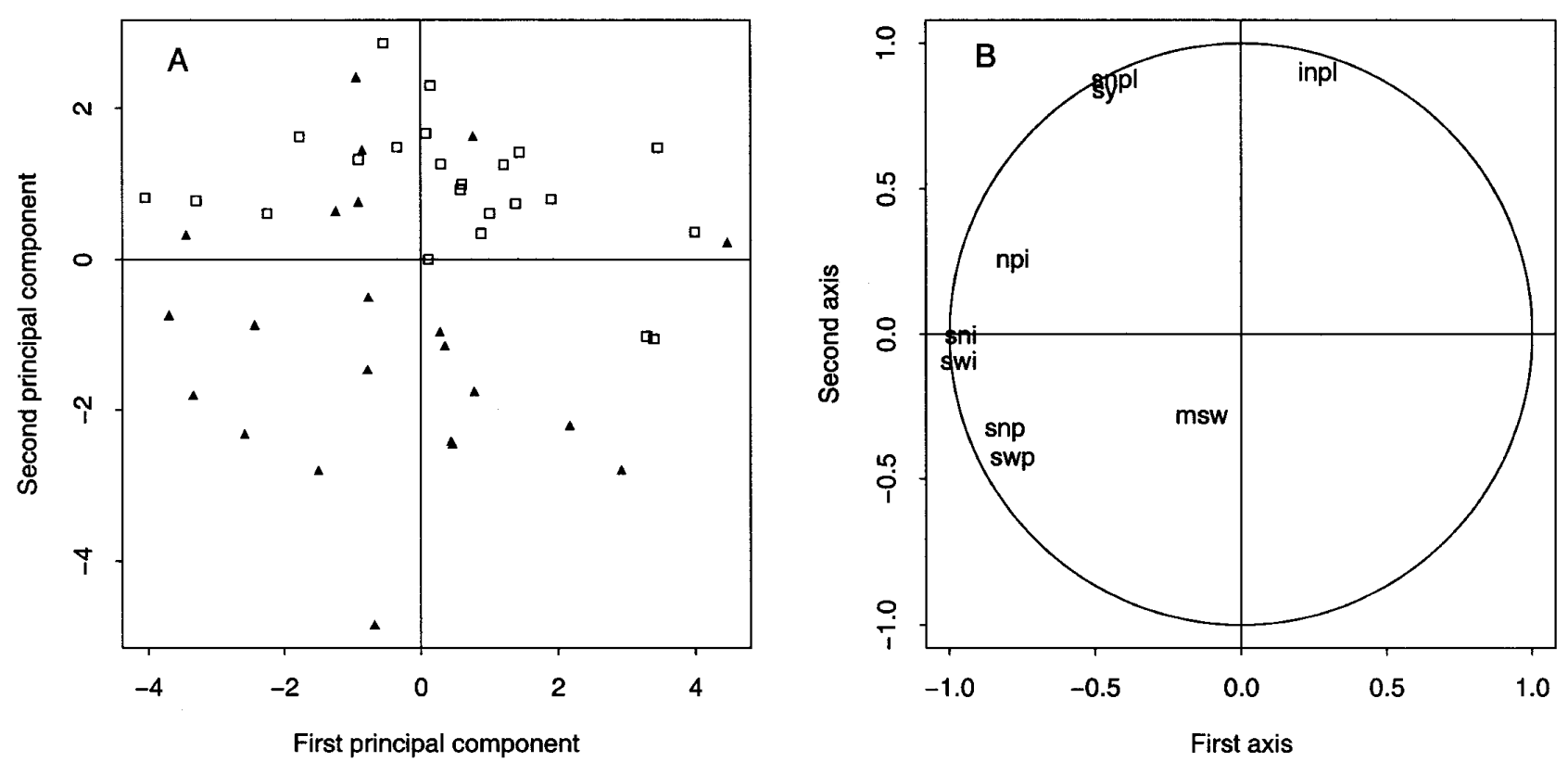

Figure 3. PCA diagrams for the cultivated populations. A shows the distribution of the populations on the first two axes of the PCA. The contribution of the variates to the axes 1 and 2 is shown in B. Symbols: $\mathbf{\Delta}$ : Mediterranean populations; $\square$ : Nordic populations. Variates: sy: seed yield per plant; snpl: seed number per plant; inpl: inflorescence number per plant; npi: number of pods per inflorescence; sni: seed number per inflorescence; swi: seed weight per inflorescence; snp: seed number per pod; swp: seed weight per pod; msw: mean seed weight. 


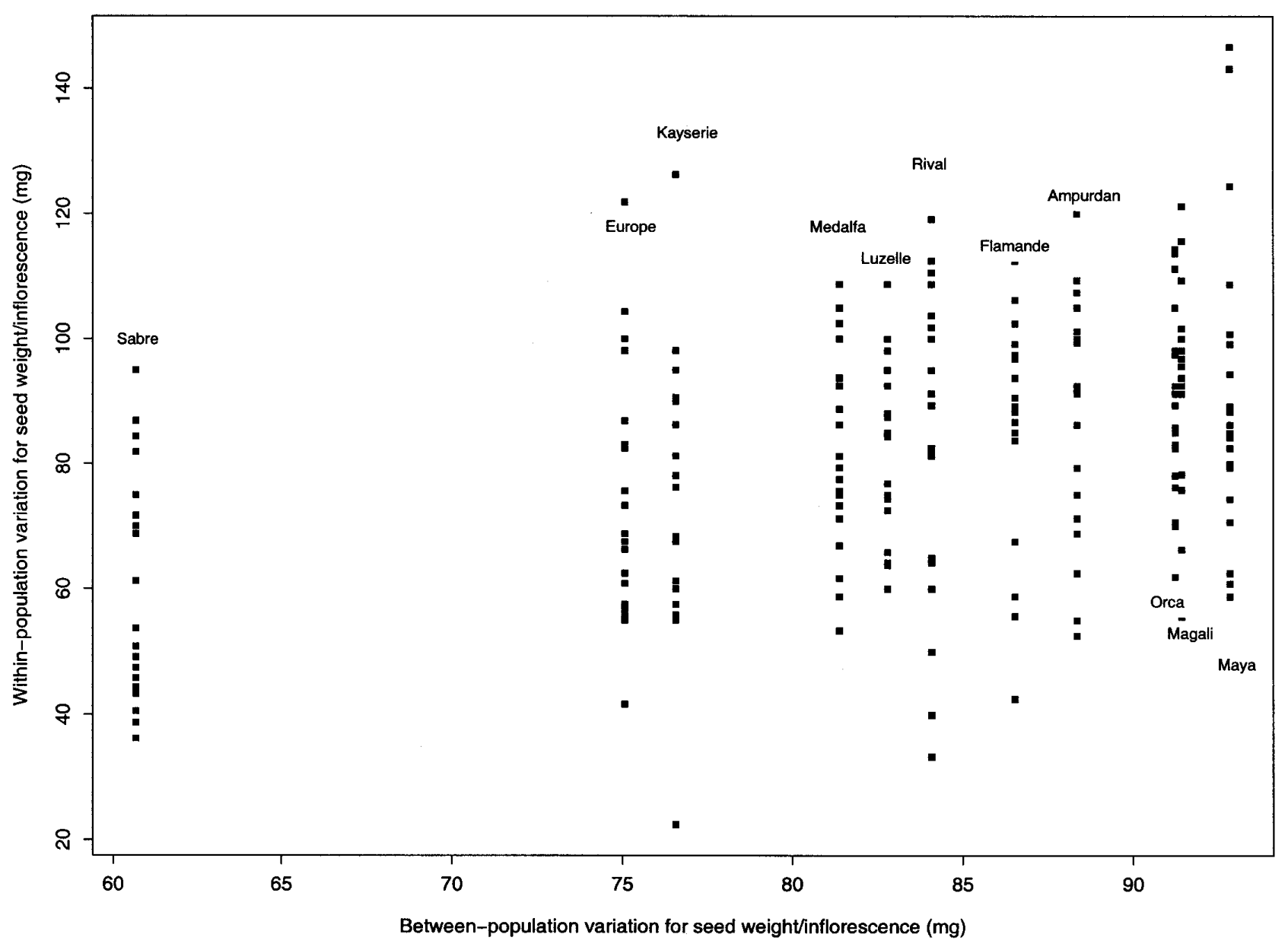

Figure 4. Among- and within-population variation for seed weight per inflorescence evaluated in 11 alfalfa populations.

genetic variance, the lowest value being found for the number of seeds per inflorescence and the highest for the number of seeds per plant. Seed yield per plant variation ranged from 9.37 to $18.32 \mathrm{~g}$ among populations and from 0.30 to $30.75 \mathrm{~g}$ within populations. Mean seed weight per inflorescence ranged from 61 to $93 \mathrm{mg}$ among populations, and from 20 to $140 \mathrm{mg}$ within populations (Fig. 4).

The broad-sense heritabilities for all characters were relatively low because of the large error variance. They varied from 0.27 to 0.43 , the highest values being found for seed yield and number of inflorescences per plant. Phenotypic and genetic correlations between seed yield components are presented in Table IV. In general, estimates of the phenotypic and genetic correlations between all pairs of the nine seed yield characters measured on individual plants were similar. Phenotypic correlations showed that all the components were associated with seed yield, the correlations decreasing progressively according to the scale of the component under consideration. Thus, the highest correlations were found for the traits measured at the plant scale, and the lowest at the pod scale.

With respect to the genetic correlations, number of seeds per plant and number of inflorescences per plant also had the highest correlations with seed 
yield per plant. The number of inflorescences per plant was only positively correlated with seed yield per plant and number of seeds per plant. As in experiment I, the number of pods and seeds per inflorescence were positively related to the seed weight of inflorescences, the number of seeds and seed weight per pod were positively correlated with seed weight per inflorescence and mean seed weight with the seed weight per pod.

\section{Discussion}

Both experiments clearly showed a large among-population range of variation for all the seed yield components. Experiment II underlined that within-population variation was larger than the among-population variation. Julier et al. [18] found a large within-population variation compared to among-population variation for quality and morphological characters. They reported a within-population variation accounting for 31 to $70 \%$ of the total genetic variance for quality and 57 to $100 \%$ for morphological components. Similarly, Crochemore et al. [7], using RAPD markers, found that within-population variation accounted for $50 \%$ of the total genetic variance. These large withinpopulation variations are similar to those reported for other tetraploid cross-pollinating species such as Trifolium pratense (Kongkiatngam et al. [20]). The large within-population variation found in the alfalfa populations is a feature of outcrossing in natural populations or synthetic varieties [11] and underlines the broad diversity available for breeding populations.

The large range of variation found for seed yield the present experiments corresponds with values reported in the literature. While we found (among 214 genotypes with four replicates) a range of 0.30 to $30.75 \mathrm{~g}$ of seed per plant, Rausch [28] reported a range from 0 to $44 \mathrm{~g}$ of seed per plant measured on 1301 individual plants of alfalfa. The within-population variation for seed yield and its components may have very diverse origins such as differences in male fertility [34], female fertility [16] and ease of tripping [19]. As early as 1937, Bolton and
Fryer [6] reported within-population variation for components related to seed yield.

In both the present experiments, the error variance contributed a major part of the phenotypic variance for all the characters. The error variance accounted for 43 to $70 \%$ of the phenotypic variance in experiment I depending on the characters and from 57 to $80 \%$ in experiment II. In both experiments, the mean seed weight had the largest error variance (66 and $80 \%$ of the total phenotypic variation for experiments I and II, respectively). These large proportions of error variance for mean seed weight correspond with a narrow range of genetic variation for seed size in cultivated alfalfa populations. To decrease the error variance, the sampling methods should be modified. The error variances tended to be larger in experiment II, except for the seed yield per plant and the number of seeds or inflorescences per plant. However, the mean values for these traits were much lower in experiment II. The larger error variances are related to sample size. Indeed, the sampling unit was four replicates of one plant (or $0.49 \mathrm{~m}^{2}$ ) for the measurement of seed yield in experiment II and three replicates of 30 plants (or $7.35 \mathrm{~m}^{2}$ ) in experiment I. For the assessment of seed weight per inflorescence, the sample sizes were three replicates of 30 inflorescences and four replicates of four inflorescences in experiments I and II respectively. Thus, the sample size should be adapted to the precision of the measurement required for breeding.

In experiment $\mathrm{I}$, the population $\times$ year interaction was not significant for most components, and only accounted for the $14.4 \%$ of the total phenotypic variation for the seed yield per plant and $15.2 \%$ for the number of seeds per plant. Thus, population $\times$ environment interaction does not constitute an important factor in the estimation of variance components for most seed yield components when studied in a spaced plant design, and is unlikely to reduce the efficiency of selection programs.

Because of the large error variances, the broadsense heritabilities were low for all the studied characters, but similar in both experiments, except 
for number of inflorescences per plant. This later character showed the lowest heritability $(0.28 \pm$ 0.08 ) in experiment $I$, and the highest heritability $(0.43 \pm 0.10)$ in experiment II, because of the contrasting values of error variance. Seed weight per inflorescence had a high heritability in both experiments.

In general, seed yield per plant had high and positive phenotypic correlations with seed number per plant, inflorescence number per plant and seed weight per inflorescence. The genetic correlations between these components were also strong. Seed weight per inflorescence showed high positive correlations with the number of pods and the seed weight per pod and variation may be produced from these two sources. The negative correlation found between the number of seeds per inflorescence and the mean seed weight indicates that some biological compensation may occur.

Relationships between seed yield and some of the seed yield components analyzed here have been reported before in alfalfa. Taylor and Marble [32] reported that the number of inflorescences per plant was the most influential component of seed yield. Zambrana [35] reported that the number of seeds per plant was the main component of seed yield, and that relationships between seed yield and number of fertile stems, number of seeds per pod and number of inflorescences per plant were also high and positive. Hacquet [14] and Rosellini et al. [31] reported positive relationships between seed yield and number of seeds per pod, while Askarian et al. [2] and Kowithayakorn and Hill [21] found no relationship between seed yield and number of seeds per pod under various management regimes. In the present study, the relationships between these components were either non-significant (in experiment I) or very low (in experiment II). Little information is available in the literature regarding the number of inflorescences or racemes and above all the seed weight per inflorescence. Our results suggest that the inflorescence could be an interesting target to consider in breeding for seed yield in alfalfa.

Selection criteria must take into account both dense canopy and spaced plant conditions. Our studies were performed under a spaced plant design which is necessary for the assessment of individual plants. In dense canopies, competition among plants is more severe and the main factors limiting seed yield may be different. Numerous studies have reported the effects of canopy structure on the seed yield of alfalfa, mainly as an effect of row spacing and plant density [2, 9, 21, 25]. Under a spaced plant design, the number of fertile stems and inflorescences may be more variable, depending on the size of the individual plants as found in both of our experiments, while, in dense canopies, the number of fertile stems per unit area is likely to be more stable.

It will be of interest to evaluate, in dense canopies, components related to the inflorescence, and especially seed weight per inflorescence, in a range of genotypes and environmental conditions. Because of its ability to take into account compensation within the inflorescence and because of the large genetic variation reported both among and within alfalfa populations, seed weight per inflorescence could be an interesting selection criterion for seed yield. The number of seeds and inflorescences per plant could also be considered as potential selection criteria. However, the extent of their variation is likely to be very different depending on plant density and competition among plants or stems. Also, the assessment of these two traits on an individual plant basis is very time consuming.

Acknowledgements: E.D. Bolaños-Aguilar is grateful to CONACYT (Consejo Nacional de Ciencia y Tecnologia de México), INIFAP (Instituto Nacional de Investigaciones Forestales y Agropecuarias de México) and SFERE (Société Française d'Exportation de Ressources Educatives) for financial support. J. Jousse, A. Gilly and D. Dos Pénédos, to whom gratitude is also expressed by the authors, rendered invaluable technical assistance.

\section{References}

[1] Andersen S., Relationship between dry matter and seed yield in grasses, in: G. van Bogaert (Ed.), Breeding High Yielding Forage Varieties Combined with High Seed Yield, Rep. Meeting, Eucarpia Fodder Crops Section, Merelbeke, Belgium, 1981, pp. 49-56. 
[2] Askarian M., Hampton J.G., Hill M.J., Effect of row spacing and sowing rate on seed production of lucerne (Medicago sativa L.) cv. Grasslands Oranga, N. Z. J. Agric. Res. 38 (1995) 289-295.

[3] Becker W.A., Manual of Quantitative Genetics, Washington State Univ., Washington, USA, 1975.

[4] Boçsa I., Buglos J., Seed yield and some factors influencing seed setting at the variety level in lucerne, Z. Pflanzenzuecht. 90 (1983) 172-176.

[5] Boçsa I., Pummer L., Seed production and breeding for stability of fertility, in: O. Chloupek, U. Simon (Eds.), Seed Production of Lucerne, Prague, 1997, pp. 87-93.

[6] Bolton J.L., Fryer J.R., Inter-plant variations in certain seed-setting processes in alfalfa, Sci. Agric. (Ottawa) 18 (1937) 148-160

[7] Crochemore M.L., Huyghe C., Kerlan M.C., Durand F., Julier B., Partitioning and distribution of RAPD variation in a set of population of the Medicago sativa complex, Agronomie 16 (1996) 421-432.

[8] Crochemore M.L., Huyghe C., Ecalle C., Julier B., Structuration of alfalfa genetic diversity using agronomic and morphological characteristics. Relationship with RAPD markers, Agronomie 18 (1998) 79-94.

[9] Dovrat A., Levanon D., Waldman M.A., Effect of plant spacing on carbohydrate in the root and components of seed yield in alfalfa, Crop Sci. 9 (1969) 33-34.

[10] Gallais A., Théorie de la sélection en amélioration des plantes, Masson, Paris, 1990.

[11] Gallais A., Pourquoi faire des variétés synthétiques? Agronomie 12 (1992) 601-609.

[12] Genter T., Delééns E., Fleury A., Influence of photosynthetic restriction due to defoliation at flowering on seed abortion in lucerne (Medicago sativa L.), J. Exp. Bot. 44 (1997) 1815-1823.

[13] Guy P., Ecalle C., Fosset M., Sikora Y., Critère de la productivité en semences de la luzerne, Fourrages (Suppl.) 62 (1975) 32-35.

[14] Hacquet J., Genetic variability and climatic factors affecting lucerne seed production, J. Appl. Seed Prod. 8 (1990) 59-67.

[15] Heinrichs D.H., Selection for higher seed yield in alfalfa, Can. J. Plant Sci. 45 (1965) 177-183.

[16] Huyghe C., Leneguer R., Auriel P.H., Bodin C., Ecalle C., Julier B., Genetic variation for male and female fertilities in alfalfa, in: J. Bouton, G.R. Bauchan (Eds.), Rep. 36th North American Alfalfa Improvement Conf., Bozeman, Montana, USA, 1998, p. 51
[17] Julier B., Porcheron A., Ecalle C., Guy P., Genetic variability for morphology, growth and forage yield among perennial diploid and tetraploid lucerne populations (Medicago sativa L.), Agronomie 15 (1995) 295-304.

[18] Julier B., Huyghe C., Ecalle C., Within- and among-cultivar genetic variation in alfalfa: forage quality, morphology and yield, Crop Sci. (2000) in press.

[19] Knapp E.E., Teuber L.R., Selection progress for ease of floret tripping in alfalfa, Crop Sci. 34 (1994) 323-326.

[20] Kongkiatngam P., Waterway M.J., Fortin M.G., Coulman B.E., Genetic variation within and between two cultivars of red clover (Trifolium pratense L.): comparisons of morphological, isozyme, and RAPD markers, Euphytica 84 (1995) 237-246.

[21] Kowithayakorn L., Hill M.J., A study of herbage and seed production in lucerne (Medicago sativa L.) under different plant spacing and cutting treatments in the seeding year, Seed Sci. Technol. 10 (1982) 3-12.

[22] Liang G.H.L., Riedl W.A., Agronomic traits influencing forage and seed yield in alfalfa, Crop Sci. 4 (1964) 394-396.

[23] Lorenzetti F., Relationship between dry matter and seed yield in leguminous forage plants, in: G. van Bogaert (Ed.), Breeding High Yielding Forage Varieties Combined with High Seed Yield: Rep. Meeting, Eucarpia Fodder Crops Section, Merelbeke, Belgium, 1981, pp. 57-74.

[24] Lorenzetti F., Achieving potential herbage seed yields in species of temperate regions, in: M.J. Baker, J.R. Crush, L.R. Humphreys (Eds.), Proc. XVII Int. Grassland Congr., 1993, pp. 1621-1628.

[25] Lovato A., Montanari M., Influence of row spacing and sowing rates on lucerne (Medicago sativa L.) seed production, J. Appl. Seed Prod. 5 (1987) 69.

[26] Melton B., Comparative seed and forage yield in crosses of selected alfalfa clones as compared to polycross progeny, Crop Sci. 9 (1969) 253-255.

[27] Michaud R., Lehman W.F., Rumbaugh M.D., World distribution and historical development, in: A.A. Hanson, D.K. Barnes, R.R. Hill (Eds.), Alfalfa and Alfalfa Improvement, Agronomy Monogr. No. 29, Madison, USA, 1988, pp. 25-91.

[28] Rausch H., The causes of infertility in lucerne (M. media Pers.). Investigations on correlations between factors determining seed yield, Z. Pflanzenzuecht. 51 (1964) 141-166. 
[29] Rincker C.M., Marble V.L., Brown D.E., Johansen C.A., Seed production practices, in: A.A. Hanson, D.K. Barnes, R.R. Hill (Eds.), Alfalfa and Alfalfa Improvement, Agronomy Monogr. No. 29, Madison, USA, 1988, pp. 985-1021.

[30] SAS Institute, SAS Language and Procedure: Usage, Version 6, 1st ed., SAS Institute, Cary, NC, USA, 1995.

[31] Rosellini D., Veronesi F., Falcinelli M., Lorenzetti F., Seed yield components in alfalfa materials selected for seed yield, in: G. Bauchan (Ed.), Rep. 32nd North American Alfalfa Improvement Conf., Pasco, Washington, 1990, p. 29.

[32] Taylor A.J., Marble V.L., Lucerne irrigation and soil water use during bloom and seed set on a red-brown earth in south-eastern Australia, Aust. J. Exp. Agric. 26 (1986) 577-581.

[33] Veronesi F., Falcinelli M., Grando S., Lorenzetti F., Selection for high seed yield in Medicago sativa L., Z. Pflanzenzuecht. 96 (1986) 189-192.

[34] Viands D.R., Sun P., Barnes D.K., Pollination control : mechanical and sterility, in: A.A. Hanson, D.K. Barnes, R.R. Hill, (Eds.), Alfalfa and Alfalfa Improvement, Agronomy Monogr. No. 29, Madison, USA, 1988, pp. 931-960.

[35] Zambrana T., Components of seed yield in different varieties of alfalfa, Rev. Cubana Cienc. Agric. 6 (1972) 289-299. 